\title{
CHARACTERIZATION OF FAMILY POULTRY PRODUCTION SYSTEM IN THE RURAL SECTOR OF AL-SHARKIA GOVERNORATE, EGYPT
}

\author{
H.B. Gharib ${ }^{1}$, Y.A. Abdel-Aziz ${ }^{2}$, M.A. El-Menawey ${ }^{1}$ and R.E. Hamouda ${ }^{2}$ \\ 1- Department of Animal Production, Faculty of Agriculture, Cairo University, Giza, Egypt, 2- \\ Department of Animal Production Systems Research, Animal Production Research Institute, \\ Agricultural Research Center, Ministry of Agriculture, Dokki, Giza, Egypt
}

\section{SUMMARY}

A longitudinal data collection (repeated survey) and a cross sectional survey was conducted in twenty-four villages in three districts; Menia El-Kamh, Hahya and Fakos in Al-Sharkia governorate, which is located in the north eastern region of Egypt. The objectives of this study were to describe the existing village poultry production systems. Using a systematic random sampling technique, one hundred and thirty-five households were randomly selected in the survey. The system identified was family poultry production system; involves two sub-systems: small-scale system and medium-scale system. The family small-scale system represented about $21 \%$ of the studied farms versus $79 \%$ for the family medium-scale. The results showed that, the family poultry production system (small-scale and medium-scale systems) in the studies area were based on indigenous chickens with scavenging and seasonal supplementary feeding depends on the quantity of the available resources. The householders supply little by the end of agricultural season when the feed resource is becoming scarce in the house. The supplementary feed in the surveyed area includes home-made ration (included maize and soya been), green forage and kitchen refusals in the small-scale and medium-scale systems. The overall mean flock size for the study area was 7.25 and 28.3 birds in the small-scale system and medium-scale system, respectively. The overall mean cocks:hen ratio was 1:5.8 and 1:2.1 in the small-scale system and medium-scale system, respectively. It was also observed that $57.14 \%$ and $8.41 \%$ of householders in the small-scale and medium-scale systems, respectively, have coops for their chicken. About 17.86\% and $57.94 \%$ of householders in the small-scale system and medium-scale system, respectively, have a room beside their houses to keep the birds. In 25\% and 33.64\% of householders in the small-scale system and medium-scale system, respectively, the birds were kept in a room inside the house.

Keywords: Village poultry production systems, small-scale, medium-scale, indigenous chickens, scavenging

\section{INTRODUCTION}

Rural Poultry production can be one of the tools to combat food insecurity and a first step in a path leading people out of poverty (Jensen and Dolberg, 2003; Alders, 2004 and Alexander et al. 2004). In a large number of low income countries, backyard/household production is the prevailing system of poultry production and is a critical source of income and nutrition for poor households. In Ghana, for example, rural poultry includes for 60-80 percent of the national poultry population (Aning, 2006). In North-eastern Nigeria, Kushi et al. 1998 reported that more than 70 percent of rural households kept chickens. Information from Bangladesh and Nigeria, where detailed disaggregated data on the structure of poultry population is available, indicates that backyard/household production accounts for more than 90 percent of the poultry population. Even in countries with a relatively large modern industrial poultry production sectorIndia for example-free ranging chicken running around in backyards of rural households are a common sight especially in areas with high incidence of poverty and it account for a very large proportion of the national poultry population. Similarly, in Vietnam, approximately half of the households keep chickens in the backyard with an average flock size being about 16 birds (Otte, 2006). In early 1990s, almost 99 percent of the chickens in Thailand were in the backyard production system (Kehran, 1999). In general, in this system the poultry are kept in low-input and low output system managed by women and children of the household (Shinde \& Srivastava, 2006, Sethi, 2007). Poultry production requires the lowest capital investment of any livestock species and has a short production cycle (Lough et al., 2001). Hosny (2006) stated that in Egypt, most families keep poultry in their backyards or on rooftops. The same author also mentioned that, the exact numbers of the rural poultry population, backyard family production, rooftop systems are not known. According to a household expenditure survey for Egypt, poultry products account for nearly one third of the expenditure on animal protein products and account for 31 percent of the total food bill

Issued by The Egyptian Society of Animal Production 
(AAFC, 2004). There is little available information about the flock size and management of rural chicken flocks and technological improvements that could be affordable to the low-input systems. Therefore, the present study aims to describe the present situation of the rural chicken production through a field survey in Al-Sharkia governorate using a specially designed questionnaire.

\section{MATERIAL AND METHODS}

The present study was conducted at the governorate of Al-Sharkia which is located in the north eastern part of Egypt. The selection of households for the study was done using systematic random sampling techniques. The survey covered 135 households located in 24 villages within 3 districts (each district contains eight villages); from every district 45 households were randomly selected as showed in Table 1. The objectives of this study were to describe the existing village poultry production systems. The data were collected during the period from June- December 2011, by using semi-structured interviews with questionnaires. The detailed questionnaire for collecting baseline data on the rural poultry production systems included information on flock size, flock structure, housing systems, feeding systems, labour, importance and utilization of the chickens.

Enumeration data of the field survey were analyzed and differences between systems were tested by chi-square procedure (Snedecor and Cochran, 1993). The data collected on flock size were statistically analyzed by the least squares procedure of the general linear model (GLM) of SAS program (SAS, 2004) version 9. The separation of means was done using the Duncan's New Multiple Range test (Duncan, 1955) for comparisons among the significant means.

The fixed model used in the analysis was: Yijk $=\mu+S_{i}+D_{i}+V_{k}\left(D_{j}\right)+e_{i j k}$ where: Yijk is the value of the respective variable, $\mu$ is the overall mean of the respective variable, $\mathrm{S}_{\mathrm{i}}$ is the effect due to the $i^{\text {th }}$ production system, $i=$ $1,2(1=$ Small-scale, $2=$ Medium-scale $), D_{j}$ is the effect of the $\mathrm{j}^{\text {th }}$ district $(\mathrm{j}=1,2,3), \mathrm{V}_{\mathrm{k}}\left(\mathrm{D}_{\mathrm{i}}\right)$ is the effect of the $\mathrm{k}^{\text {th }}$ village within district $\mathrm{j}$, $(\mathrm{k}=1, \ldots, 8), \mathrm{e}_{\mathrm{ijk}}$ is a random error associated with the $\mathrm{ijk}^{\text {th }}$ observation and is assumed to be independently and normally distributed.

\section{RESULTS AND DISCUSSION}

In the studied area, the system identified in the rural poultry production systems was family poultry production system; that involves two sub-systems: small-scale and medium-scale village poultry production systems.

\section{Brief description of the system}

Family poultry production system: Family poultry production is the prevailing system in nearly all the rural sector. The economic purpose of the poultry farmer is mainly to meet family needs (home consumption), also it is considered as extensive system (EL-Wardani et al., 2008). Family poultry production was defined as flocks of less than 100 birds (Sonaiya, 1990). This system involves two subsystems according to flock size; small-scale and medium-scale village poultry production systems

\subsection{Small-scale village poultry production system: \\ Flock size in this system ranged from 1-15} bird (Table 2). This system represented about $21 \%$ (28 farmers) of the total farmers surveyed. In this system poultry used for home consumption of the family in most cases.

\subsection{Medium-scale village poultry production system: \\ Flock size in this system ranged from 16-} 100 bird (Table 2). This system represented about 79\% (107 farmers) of the total farmers surveyed. In this system poultry used for home consumption and also provide income for the family.

\section{Flock size:}

The mean of flock size was significantly $(\mathrm{P}<0.0001)$ lower under the small-scale system ( 7.25 birds) ranged from 1-15 birds, than the medium-scale system (28.3 birds) ranged from 16-100 birds (Table 2).

The flock size was reported in previous studies in Egypt to range from as few as 10-20 birds up to a few hundreds depending on the objectives of the farmers (Hosny, 2006), while in the Philippines it ranged from 4-130 birds (Lambio, 2005). Eugene (2004) of the Philippines, Ssewannyana et al. (2003) of Uganda, and Khalafalla (2000) of Sudan reported mean flock sizes of 19, 18 and 22 birds, respectively. The flock size variation in rural areas has been attributed to household size and capital investment in chicken rearing, home consumption and use as farm income. In addition, the flock variation might be due to chicken market availability, market prices or market seasonality.

Analysis of variance for flock size showed significant effects among systems $(\mathrm{P}<0.0001)$, and between villages within districts $(\mathrm{P}<0.0001)$ as shown in Table (3). However no significant differences were detected among districts which indicate the similarity among them as far as poultry production is concerned. 
Flock structure and characteristics of the flock:

Flock structure is described in terms of the number and proportion of different age and sex groups in the flock as shown in Table 4. In the small-scale group; mean number of chicks was 0.71 and 4.60 hens per household. While in the medium-scale group there were 7.96 hens and 4.08 chicks per household. Similar results were reported by Asefa (2007), who stated that the mean number of chickens in a flock were 2.5 hens and 3.8 chicks, in the medium-scale system. Considering the proportion of chicken in the surveyed households, their proportional distribution in different age categories varied considerably. The proportion of hens was $63.5 \%$ in the small-scale and about $28.14 \%$ in the medium-scale system. The relatively large proportion of hens, per household, in the surveyed area was done, by the farmers, aiming to secure the next generation of the flocks.

Both the number and proportions of cocks per household accounted for 10.84 and 13.38 $\%$, in the small-scale and medium-scale systems, respectively. Farmers in the study area have the experience to remove extra males from the flocks at an early age for sale and sometimes for consumption. During the group discussions, they mentioned that, they remove males to minimize cock fighting and to maintain the male to female ratio. The male to female ratio was $1: 2.1$ in the medium-scale system and 1:5.8 in the small-scale system. This result is within the ratio reported in free range and backyard chicken production systems for Africa, 1:1and1:8 respectively, (Guèye, 2003). The difference in flock structure between the small and medium-scale systems was statistically significant (Table 4).

\section{Characteristics of the Chicken strains:}

As presented in Table (5) since the smallscale system is a scavenging type of production with occasional and seasonal supplementary feeding of homegrown grains and household food refusals this led to using indigenous or native chicken $(75 \%)$ such as Fayoumi, Balady and Dandarawy. However, $25 \%$ of the families used improved chicken strains such as Dokki4, Mandarah, Montazah, Matrouh, Bandara, El-Salam and Baheig. The medium-scale system families used about $29.91 \%$ indigenous or native chicken and $70.09 \%$ improved chicken strains. The results showed that the two types of production systems are significantly $(\mathrm{P}<0.001)$ different from each other. Most farmers prefer to keep improve strains due to their high price in the local market.

In Egypt, native breeds of poultry of different species are the majority kept by farmers. This is followed in number by those who keep improved native breeds and lastly by exotic breeds. The largest percentage of chicken of native breeds such as Fayoumi, Balady and Dandarawy are kept in traditional and landless systems $(77 \%$ and $61 \%$ respectively) (Ek-Wardani et al., 2008). No specific breed could be pinpointed in the rural poultry sector of Egypt, as it depends mainly on the local non-specified crosses between endogenous native breeds such as Fayoumi, Balady and Dandarawy or improved native breeds (Hosny, 2006).

Data indicated that the chicken populations in all the study areas are increasing largely due to growth in demand and higher prices of chicken and eggs. The most important reasons for keeping chickens and producing eggs by farmers were as a source of income and for hatching. The color of the local chickens found in the study area includes pure colors of black, white, red, grey and mixtures of different colors (red with black spots, white with black spots etc.).

\section{Source of Chickens}

The results of the study area, as shown in Table 6, indicated no statistically significant difference, in sources of chickens between the two systems (small-scale and medium-scale). The results indicated that the traders are the main source of the chickens in small-scale and medium-scale systems $(64.29 \%$ and $57.01 \%$, respectively). This reflects the importance of poultry traders in rural areas. Local hatcheries are the second source of chickens $(14.29 \%$ and $28.97 \%$ in small-scale and medium-scale systems, respectively). Moreover, the household owner's flock contribute only $17.86 \%$ and $7.48 \%$ of the replacement chickens in the small-scale system and medium-scale system, respectively. Market was a poor source for chicken replacement in small-scale and medium-scale systems (only $3.57 \%$ and $6.54 \%$, respectively).

According to El-Wardani et al. (2008), in Egypt, the traders are the main source of chickens (mainly day-old chicks) in the different production systems. Traders are the source of $41 \%-61 \%$ of the chickens in the surveyed farms depending on the system. Local hatcheries are the only source of chickens in $5-14 \%$ of the cases. Governmental sites in Fayoum such as Al-Azzab integrated 
project and poultry research satiations are good source for chickens in the Semicommercial and landless systems $(23 \%$ and $48 \%$, respectively).

In Ethiopian, Fisseha et al. (2010) reported that about $50 \%$ of the respondents started chicken rearing by their own interest and the major source of chicken for parent stock (93.9\% for Bure, $43.7 \%$ for Fogera and $97.5 \%$ for Dale) is market purchase. The majority of the replacement stocks $(75.5-87.2 \%)$ originate from their own chicken and the rest are purchased from the local market. Some farmers keep the exotic Rhode Island Red (RIR) breed that was distributed through the government extension system and in some instances have been crossed with local chicken strains.

\section{Feed and feeding systems}

The major feed and feeding practice of the study area are summarized in Table7. The differences, in feeding systems between the two systems (small-scale and medium-scale) were statistically significant. The results indicated that the scavenging system alone was observed in the small-scale system only $(3.60 \%)$. The scavenging plus supplement feeding system in the surveyed area represented all the proportion of the householders in the medium-scale system and $96.40 \%$ of the householders in the small-scale system.

All the householders in the medium-scale system added supplementary feed to their chicken. This includes home-made ration (maize and Soya been), green forage and kitchen refusals. However, $47.65 \%$ of the householders in medium-scale system used commercial ration as a supplement only. Young chicks were given supplementary feeding in all the study area because they could not scavenge (Table 7).

Tadelle et al. (2003) listed insects, grass and harvest leftovers as source of scavenging for village chicken in Ethiopia. Also supplementary feed is composed of a mix of various crops produced on-farm. According to Fisseha et al. (2010) in Ethiopia the nutritional management practiced is predominantly scavenging with some sort of supplementary feeding during the rainy rather than the dry season. This coincides with the shortage of grain during the rainy season. These amounts of additional feed provided depend upon the availability of resources in the house. Scavenging feed resources consist of grasses, insects and worms, crop leftovers and household leftovers. Wheat, maize and household leftover are the major types of feeds supplemented to chicken. Other minor feed types include finger millet, barely, rice, injera, and bran. Lack of feed supplementation is one of the characteristics of a free-ranging backyard poultry production system (Gueye, 2003).

In Sudan, Khalafalla (2000) reported that scavenging is the only feeding system. Chickens feed on insects, grass, vegetables, kitchen wastes or dry bread. Almost all households gave feed supplements to their chickens. Cereals were the most dominant feed supplements. However, some provided wheat bran, sesame or alfalfa and in one occasion a formulated layer diet was given.

Our results indicated that the differences, in feeding practice between the two systems (small-scale and medium-scale) were statistically significant (Table 7). More of the small-scale householders (25\%) throw feed for their chickens on ground (Table7). However, only $4.67 \%$ of the medium-scale system feed their chickens this way.

In the study area, the differences, in source of feed container between the two systems (small-scale and medium-scale) were statistically significant (Table 7). The results indicated that $89.28 \%$ of the small-scale system householders depended on old kitchen wear as source of feed container in the. However, only $40.19 \%$ of the medium-scale system householders used old kitchen ware, for feeding their chickens. It is clear from this results that the medium-scale system could be looked at as a transitional stage towards the semi-intensive system.

In most cases, provision of supplementary feeds to chicken was seasonal. It also depends on the quantity of the available feed resources. The householders supply little feed by the end of the agricultural season when the feed resource is becoming scarce. As presented in Table (7) there was a statistically significant difference, in the type of supplementary feeds, between the two systems (small-scale and medium-scale).

Also there was no significant difference, between the two systems (small-scale and medium-scale) in the frequency of offering the supplementary feed to the chickens (Table 7). It is worth mentioning that in the small-scale and medium-scale systems, usually, householders give supplementary feed to their chickens in the morning and the evening, which seem a common practice in the study area. However, there is a need to investigate further the quality and quantity of supplementary feeds in the study area.

\section{Housing}

Housing is essential to chickens as it protects them against predators, theft, weather (rain, sun, cold wind, dropping night temperatures) and to provide shelter for egg 
laying and broody hens. The survey presented in Table 8 revealed that, there was no significant difference, between the two systems (small-scale and medium-scale) in the type of housing used for chickens. However, most of householders in the small-scale system used coops to keep their chickens for minimizing costs. However, due to the large flock size of the chicken in the medium-scale system the householders in this system tend to keep their chickens in separated places from their homes. About $57.14 \%$ of the householders in the small-scale system have coops for their chicken, and $57.94 \%$ of the householders in the medium-scale system have a room beside their houses for chicken. Also, 33.64\% of the householders in the medium-scale system kept their birds in a room inside the house.

Differences, in the housing materials, between the two systems (small-scale and medium-scale) were statistically significant (Table 8). The study showed that the most of the householders in the small-scale system used adobe bricks and wood to build their chickens houses $(35.71 \%$ and $28.57 \%$, respectively). In the medium-scale system, most of the householders $(58.88 \%)$ used red bricks for building their chickens houses.

The results (Table 8) indicated no statistically significant difference, in materials that householders were used in building ceilings of their chicken houses between the two systems (small-scale and medium-scale). The householders depended on local available material in rural areas such as concrete, mud, ditch reed and wood for building ceiling.

Results represented in Table 8, indicated no statistically significant differences in the type of litter used in chicken houses between the two systems (small-scale and medium-scale). A large proportion of householders in smallscale and medium-scale systems used dust, as litter, in their chicken houses. Moreover, there is little proportion in two system used wheat straw as a litter in their chicken houses. This was related to the available material, in rural areas, and costs.

The present results are in agreement with these reported by El-Wardani et al. (2008). They stated that poultry in the traditional and landless systems are usually housed in primitive coops that are built from locally available materials in rural areas such as mud bricks and palm wood, reed or plant stalks. In most cases, these houses are located either on the rooftops or attached to the house, have no artificial light, and with small windows. They reported that the coop represents the largest percentage $(73 \%$ and $76 \%)$ for the traditional and landless systems, respectively.

\section{Household labour}

In the present study all members of the family in the studied households participate in chicken keeping and management practice in one way or another (Table 9). In the study area, daily managerial practices which depend mainly on women were $82.14 \%$ and $63.55 \%$ of the surveyed poultry farmers in the small-scale system and medium-scale system, respectively. The difference between the two systems (small-scale or medium scale) was not statistically significant.

Our results are in agreement with these found by El-Wardani et al. (2008). They reported that, in Egypt all the family members including women, children and men tend to be involved in rural poultry production. Women, assisted in some cases by children, play a key role in the family labour. They stated that the daily managerial practices depend mainly on the women in $65 \%$ and $70 \%$ of the surveyed poultry farmers in traditional and landless systems, respectively.

\section{Importance and utilization of the chickens}

Differences, in the objective of the householders to either produce eggs or live hens between the two systems (small-scale and medium-scale) were statistically significant (Table 10). The results from this study showed that Poultry owner's objective is usually more related to the production system. The two systems (small-scale and medium-scale systems) are mainly directed towards live chicken production for home consumption. The surplus chickens or eggs are sold in the local markets to increase family income in the small-scale system. Ten present of the farmers, in small-scale system, sold their chickens and chickens products directly to the consumers in villages and urban markets $5 \%$ of the live chicken and $5 \%$ of the eggs). A similar trend was observed in the medium-scale system. Farmers sold $20 \%$ of the live chicken and $64.3 \%$ of the eggs directly to the consumers in villages and urban markets. Moreover, the present results showed that $18 \%$ and $20.5 \%$ of egg production is used for flock replacement in the small-scale and medium-scale systems, respectively. The other purpose of chicken production, identified by the respondents, in order of importance, was for home consumption and using chicken for religious occasions. 
Previous studies indicated that, in Egypt, small and medium poultry owner's objectives are usually more related to the production systems. Traditional and landless systems are mainly directed towards home consumption (67\% and $58 \%$, respectively). The surplus is sold in the local markets to increase family income (EL-wardani et al., 2008).

However, in Ethiopia, Fisseha et al. (2010) reported that, purposes of chicken production are the sale of live chicken for cash income is the rearing chicken in Fogera $(77.8 \%)$ and Dale $(43.7 \%)$ districts. In Bure, however, egg hatching for production of replacement chicks $(51 \%)$ and sale for income $(43.5 \%)$ are found to be important. Although village chicken production is a viable and promising alternative source of income for rural households in developing countries (Oh 1990), its contribution to the household cash income is generally difficult to assess.

\section{CONCLUSION}

The most dominant chicken production systems in the study area were the family poultry production system. Labour is not regularly paid, but is drawn from the family household. Family poultry was additionally clarified as small-scale and medium-scale flocks managed by individual farm families in order to obtain food security, income and gainful employment for women and children. Despite the many problems involved in keeping poultry, nearly all households provided supplementary feed and water to their chickens, and this could be considered as the strength of the sector. Almost all the interviewed farmers also need to pursue boosting up the chicken production. This is perhaps considered as an opportunity and potential for poultry production and development endeavors in the study area. Flock size can be increased through administering small-scale or mini hatcheries at the village level or at the district level that could collect and use local eggs. It is important to focus on working with women's groups, both to use their knowledge about poultry production, and to improve their incomes. There is a need to make readily available credit services particularly intended for poultry production and this calls for special and urgent intervention by concerned government institutions, research institute and universities.

\section{REFERENCE}

AAFC, Agriculture and Agri-Food Canada, 2004. Market Information Africa and the Middle East, July 2004.
Alders, R., 2004. Poultry for profit and pleasure. FAO Diversification Booklet 3. FAO.

Alexander, D.J.; Bell, J.G. and Alders, R.G., 2004. Technology Review: Newcastle disease with special emphasis on its effect on village chickens. FAO Animal Production and Health Paper No. 161. Rome, FAO. 63pp.

Aning, K.G., 2006. "The Structure and Importance of Commercial and Village Based Poultry in Ghana", Poultry Review Report prepared for FAO, Acra, Ghana.

Asefa, T., 2007. Poultry management practices and on farm performance evaluation of Rhode Island Red (RIR), Fayoumi and local chicken in Umbullo Wachu watershed. M. Sc. thesis. Department of animal and range sciences, Hawassa College of agriculture, Awassa, Ethiopia.

Duncan, D.B., 1955.The Multiple Range and multiple F-tests. Biometrics, 11: 1-42.

El-Wardani, M.A.; Abdel-Aziz, A.Y.; Amal, S.O.; Abdelmaged, A.H. and Zatter, O.M. 2008. Characterization of poultry production systems in the rural sector of Fayoum. Egyptian J. Anim. Prod., 45 Suppl. Issue, Dec.; 85.96.

Eugene, F., 2004. A longitudinal analysis of chicken production systems of smallholder farmers in Leyte, Philippines. Leyte State University, Leyte, The Philippines.

Fisseha Moges Azage Tegegne and Tadelle, 2010. Dessie Indigenous chicken production and marketing systems in Ethiopia: Characteristics and opportunities for market-oriented development. Improving Productivity and Market Success (IPMS) of Ethiopian Farmers Project, International Livestock Research Institute (ILRI), P.O. Box 5689, Addis Ababa, Ethiopia.

Guèye, E.F., 2003. Poverty alleviation, food security and the well-being of the human population through family poultry in low income food-deficit countries. Senegalese Institute of Agricultural research (ISRA), B.P.2057, Dakar-hann, Senegal.

Hosny, F.A., 2006. The structure and importance of the commercial and village based poultry system in Egypt. FAO publications.http://

www.fao.org/avianflu/en/farmingsystems.h $\underline{\mathrm{tml}}$

Jensen, H.A. and Dolberg, F., 2003. A conceptual framework for using poultry as tool in poverty alleviation, International Conference on Staying Poor: Chronic poverty and Development Policy, IDPM University of Manchester, April 7 to 9. 
Kehran Tatjana, 1999. Women, Common Property Resources and Livestock Husbandry in Thai Villages, International Journal of Social Economics, 26 (1-3):370388.

Khalafalla, S.W.H., 2000. Village poultry production in Sudan, Department of microbiology, Faculty of veterinary science, University of Khartoum, Khartoum, North Sudan

Kushi, D.H.; Adegbola, T.A. and Umeh, A.P., 1998. The Role of Women in Animal Production, In: Animal Agriculture in West Africa: The Sustainability Question (Oduguwa, O.O., Fanimo, A.O. and Osinowo, O.A., Eds.). Proceedings of the Silver Anniversary Conference of the Nigerian Society for Animla Production and the Inaugural Conference of the West African Society for Animal Production held on March 21-26, 1998 at Gateway Hotel, Abeokuta, Nigeria, pp. 254-255.

Lambio, A.L., 2005. The Future Prospects for Smallholder Native Chicken Producers in the Philippines. Elpidio Quirino Professorial Chair Lecture. 24 June. ADSC Lecture Hall, UPLB-CA

Lough, R.; Morgan, I.; Walls, J.; Escrivão, R. and Ferrão, 2001. Report to IFAD on the contribution of livestock to poverty alleviation in Mozambique. GRM International Pty Ltd. MADER, Maputo, Mozambique.

Oh, B.T., 1990. Economic importance of indigenous chickens in west Malaysia. In: Proceedings, CTA seminar, 3rd international symposium on poultry production in hot climates, Hamelin, Germany.

Otte, J., 2006. The Hen Which Lays the Golden Eggs: Why Backyard Poultry are so popular? PPLPI Feature, www.fao.org/ag/pplpi.html.

SAS, 2004. SAS User's Guide: Statistics, Version 9.1. SAS Inst. Inc., Cary, NC., USA.
Sethi, B., 2007. Backyard Poultry in Orissa. http://orissagov.nic.in/e-magazine/ Orissareview/ jan-2007/engpdf/48-52.pdf

Shinde, P.K.. and Neeraj Srivastava., 2006. Adaptive Research Interventions on Household Poultry: Lessons Learned and Feedback for Further Research. In: Sasidhar, P.V.K. (Ed.). Poultry Research Priorities to 2020, Proceedings of National Seminar, November 2-3, 2006. Central Avian Research Institute, Izatnagar. pp. 239-243.

Snedecor, G.W. and Cochran, W.G., 1993. Statistical methods ISBN: 0-8138-1561-4.

Sonaiya, E.B., 1990. ANRPD Proceedings International Network for Family Poultry Development (INFPD): origins, activities, objectives and visions. In F. Dolberg \& P.H. Petersen, eds. Poultry as a Tool in Poverty Eradication and Promotion of Gender Equality, pp.39-50. Proceedings Workshop, March 22 /26, 1999, Tune Landboskole, Denmar (also available at http://www.husdyr.kvl.dk/htm/php/tune99/ 4-Sonaiya.htm).

Ssewannyana E.; Ssali, A.; Kasadha, T.; Dhikusooka, M.; Kasoma, P.; Kalema, J.; Kwatotyo, B.A. and Aziku, L., 2003. Characterisation of indigenous chickens in Uganda. In Proceedings of the Livestock Systems Research Programme Annual Scientific Workshop, held March 2003, Kampala, Uganda pp. 161-171. DANIDA's Agricultural Sector Research Programme (ASPS) and National Agricultural Research Organisation (NARO) Uganda.

Tadelle, D.; Million, T.; Alemu, Y. and Peter, K.J., 2003. Village chicken production system in Ethiopia. Use patterns and performance evaluation and chicken products and socio-economic function of chicken. Humboldt University of Berlin, animal breeding for tropics and sub tropics. Philoppstr.13, Hause 9, 10115, Berlin. 
Table 1. Number of surveyed Chicken farmers at different villages

\begin{tabular}{|c|c|c|}
\hline Districts & Villages & Farmers \\
\hline \multirow{8}{*}{ Hahya } & Abo-Wasia & 6 \\
\hline & Abo-Zaton & 4 \\
\hline & El-Abasy & 9 \\
\hline & Kaffer-Dabos & 4 \\
\hline & Khalwt-Dabos & 5 \\
\hline & Manzel-Hayan & 7 \\
\hline & Abo-Daba & 5 \\
\hline & Mena & 5 \\
\hline \multirow{8}{*}{ Menia EL-kamh } & Abo-Twala & 6 \\
\hline & Al-Azezia & 12 \\
\hline & Al-Koba & 9 \\
\hline & El-Sanafen & 3 \\
\hline & Menia El-Kamh & 3 \\
\hline & Met-Sehal & 5 \\
\hline & Met-Yazed & 3 \\
\hline & Sinahwa & 4 \\
\hline \multirow{8}{*}{ Fakos } & Al-Azazy & 5 \\
\hline & Al-Zahayra & 6 \\
\hline & El-Dedamon & 5 \\
\hline & El-Fadadna & 6 \\
\hline & Kayad El-Badria & 5 \\
\hline & Met El-Ez & 7 \\
\hline & Samaken El-Gharb & 7 \\
\hline & Tarat El-Shabab(1) & 4 \\
\hline
\end{tabular}

Table 2. Chicken flock size under family poultry production systems

\begin{tabular}{lcc}
\hline Production systems & Small-scale & Medium-scale \\
\hline Number of questionnaires & 28 & 107 \\
Percent of questionnaires & 21 & 79 \\
Flock size (birds) & $1-15$ & $16-100$ \\
Mean flock size \pm SE & $7.25^{\mathrm{b}} \pm 0.39$ & $28.3^{\mathrm{a}} \pm 1.4$ \\
\hline
\end{tabular}

${ }^{a-b}$ Means within a row with different superscript difference significantly $(\mathrm{P}<0.0001)$

Table 3. Analysis of variance of flock size by system, district and village within distric

\begin{tabular}{lcccc}
\hline Source of variation & DF & SS & M S & Pr $>$ F \\
\hline System & 1 & 9953.38 & 9953.38 & $<0.0001$ \\
District & 2 & 233.38 & 116.69 & 0.3271 \\
Villages within districts & 7 & 6872.98 & 981.85 & $<0.0001$ \\
Model & 10 & 19431.1 & 19431.1 & $<0.0001$ \\
Error & 124 & 12831.28 & 103.48 & \\
Corrected Total & 134 & 32262.4 & & \\
\hline
\end{tabular}

Table 4. Chicken flocks structure under family poultry production systems

\begin{tabular}{lcccccc}
\hline \multirow{2}{*}{ Chickens Structure } & \multicolumn{3}{c}{ Small-scale } & \multicolumn{3}{c}{ Medium-scale } \\
\cline { 2 - 7 } & $\mathbf{N}$ & $\mathbf{( \% )}$ & mean/household & N & $\mathbf{( \% )}$ & mean/household \\
\hline Hens & 129 & 63.55 & 4.6 & 852 & 28.14 & 7.96 \\
Cocks & 22 & 10.84 & 0.78 & 405 & 13.38 & 3.78 \\
Pullets & 32 & 15.76 & 1.14 & 1334 & 44.06 & 12.46 \\
Chicks & 20 & 9.85 & 0.71 & 437 & 14.43 & 4.08 \\
\hline
\end{tabular}

Difference between the two production systems was significant $\left(\chi^{2}=118.33, \mathrm{P}<0.0001\right)$ 
Egyptian J. Anim. Prod. (2012)

Table 5. Chicken strains under family poultry production systems Chicken Strains Production systems

\begin{tabular}{lcccc}
\cline { 2 - 5 } & \multicolumn{3}{c}{ Small-scale } & \multicolumn{3}{c}{ Medium-scale } \\
\cline { 2 - 5 } & $\mathrm{N}$ & $(\%)$ & 32 & $(\%)$ \\
\hline Native & 21 & 75 & 75 & 29.91 \\
Improved & 7 & 25 & 70.09 \\
\hline
\end{tabular}

Difference between the two production systems was significant $\left(\chi^{2}=18.92, \mathrm{P}<0.0001\right)$

Table 6. Source of chickens under family poultry production system

\begin{tabular}{|c|c|c|c|c|}
\hline \multirow{3}{*}{ Source of chickens } & \multicolumn{4}{|c|}{ Production systems } \\
\hline & \multicolumn{2}{|c|}{ Small-scale } & \multicolumn{2}{|c|}{ Medium-scale } \\
\hline & $\mathbf{N}$ & $(\%)$ & $\mathbf{N}$ & $(\%)$ \\
\hline Owner's flock & 5 & 17.86 & 8 & 7.48 \\
\hline Traders & 18 & 64.29 & 61 & 57.01 \\
\hline Hatcheries & 4 & 14.29 & 31 & 28.97 \\
\hline Market & 1 & 3.57 & 7 & 6.54 \\
\hline
\end{tabular}

No significant difference was observed between production systems $\left(\chi^{2}=4.86, \mathrm{P}=0.1823\right)$

Table 7. Feed and feeding practices under family poultry production system

\begin{tabular}{|c|c|c|c|c|}
\hline \multirow{2}{*}{ Items } & \multicolumn{2}{|c|}{ Small-scale } & \multicolumn{2}{|c|}{ Medium-scale } \\
\hline & $\mathbf{N}$ & $(\%)$ & $\mathbf{N}$ & $(\%)$ \\
\hline \multicolumn{5}{|l|}{ Feeding systems } \\
\hline Scavenging alone & 1 & 3.60 & 0 & 0.00 \\
\hline Scavenging with supplement & 27 & 96.40 & 107 & 100 \\
\hline \multicolumn{5}{|l|}{ Types of supplementary feed } \\
\hline Commercial ration & 0 & 0.00 & 51 & 47.65 \\
\hline Green forage & 8 & 28.57 & 41 & 38.30 \\
\hline Home-made ration & 17 & 60.71 & 10 & 9.30 \\
\hline Kitchen refusals & 3 & 10.71 & 5 & 4.75 \\
\hline \multicolumn{5}{|l|}{ Frequency of feeding } \\
\hline Once a day & 1 & 3.6 & 3 & 2.80 \\
\hline Twice a day & 22 & 78.6 & 90 & 84.12 \\
\hline Three times a day & 5 & 17.8 & 14 & 13.08 \\
\hline \multicolumn{5}{|l|}{ Feeding practices } \\
\hline put feed in the container & 21 & 75 & 102 & 95.33 \\
\hline Throw on the ground & 7 & 25 & 5 & 4.67 \\
\hline \multicolumn{5}{|l|}{ Source of feeding container } \\
\hline Old kitchen wear & 25 & 89.28 & 43 & 40.19 \\
\hline Purchased & 3 & 10.72 & 64 & 59.81 \\
\hline \multicolumn{5}{|c|}{ Difference between the two production systems for feeding systems are significant $\left(\chi^{2}=3.84, \mathrm{P}=0.0497\right)$} \\
\hline \multicolumn{5}{|c|}{$\begin{array}{l}\text { Difference between the two productions systems for type of supplementary feed are significant }\left(\chi^{2}=44.57, \mathrm{P}\right. \\
<0.0001) \text {. }\end{array}$} \\
\hline \multirow{2}{*}{\multicolumn{5}{|c|}{$\begin{array}{l}\text { No significant difference was observed between production systems for frequency of feeding }\left(\chi^{2}=0.48, \mathrm{P}\right. \\
=0.7845) \text {. } \\
\text { Difference between the two production systems for feeding practices are significant }\left(\chi^{2}=11.32, \mathrm{P}=0.0008\right)\end{array}$}} \\
\hline & & & & \\
\hline \multicolumn{5}{|c|}{$\begin{array}{l}\text { Difference between the two production systems for feeding practices are significant }\left(\chi^{2}=11.32, \mathrm{P}=0.0008\right) \\
\text { Difference between the two production systems for source of feeding container was significant }\left(\chi^{2}=21.40, \mathrm{P}\right. \\
<0.0001) \text {. }\end{array}$} \\
\hline
\end{tabular}


Table 8. Housing systems and litter under family poultry production system

\begin{tabular}{|c|c|c|c|c|}
\hline \multirow[t]{2}{*}{ Items } & \multicolumn{2}{|c|}{ Small-scale } & \multicolumn{2}{|c|}{ Medium-scale } \\
\hline & $\mathbf{N}$ & $(\%)$ & $\mathbf{N}$ & $(\%)$ \\
\hline \multicolumn{5}{|l|}{ Type of housing } \\
\hline Coop & 16 & 57.14 & 9 & 8.41 \\
\hline Room beside the house & 5 & 17.86 & 62 & 57.94 \\
\hline Room inside the house & 7 & 25 & 36 & 33.64 \\
\hline \multicolumn{5}{|l|}{ Housing material } \\
\hline Adobe bricks & 10 & 35.71 & 32 & 29.91 \\
\hline Red bricks & 10 & 35.71 & 63 & 58.88 \\
\hline Wood and wire & 8 & 28.57 & 12 & 11.21 \\
\hline \multicolumn{5}{|l|}{ Ceiling material } \\
\hline Concrete & 6 & 21.43 & 29 & 27.10 \\
\hline Mud & 6 & 21.43 & 24 & 22.43 \\
\hline Ditch reed & 10 & 35.71 & 34 & 31.78 \\
\hline Wood and wire & 6 & 21.43 & 20 & 18.69 \\
\hline \multicolumn{5}{|l|}{ Type of litter } \\
\hline Dust & 23 & 82.14 & 79 & 73.83 \\
\hline Wheat straw & 5 & 17.86 & 28 & 26.17 \\
\hline \multirow{2}{*}{\multicolumn{5}{|c|}{$\begin{array}{l}\text { No significant difference was observed between production systems for type of housing }\left(\chi^{2}=2.43, \mathrm{P}=\right. \\
0.2963) \\
\text { Difference between the two production systems for housing material are significant }\left(\chi^{2}=2.43, \mathrm{P}=0.030\right. \\
\text { No significant difference was observed between production systems for ceiling material }\left(\chi^{2}=0.47, \mathrm{P}=0 \text {. }\right. \\
9238) \\
\text { No significant difference was observed between production systems for type of litter }\left(\chi^{2}=0.83, \mathrm{P}=0.362\right.\end{array}$}} \\
\hline & & & & \\
\hline \multirow[t]{2}{*}{ Labour } & \multicolumn{2}{|c|}{ Small-scale } & \multicolumn{2}{|c|}{ Medium-scale } \\
\hline & $\mathbf{N}$ & $(\%)$ & $\mathbf{N}$ & $(\%)$ \\
\hline Women & 23 & 82.14 & 68 & 63.55 \\
\hline children & 1 & 3.57 & 8 & 7.48 \\
\hline Family & 4 & 14.29 & 31 & 28.97 \\
\hline
\end{tabular}

No significant difference was observed between production systems $\left(\chi^{2}=3.49, \mathrm{P}=0.1745\right)$

Table 10. The importance and utilization of chickens and eggs under family poultry production system

\begin{tabular}{lcc}
\hline Items & Small-scale & Medium-scale \\
\hline Home consumption (\%) & & 15.2 \\
Eggs & 77 & 80 \\
Hens & 95 & 64.3 \\
Market (\%) & & 20 \\
Eggs & 5 & 20.5 \\
Hens & 5 & 0 \\
Flock replacement (\%) & & \\
Eggs & 18 & $0.0001)$ \\
Hens & 0 & \\
\hline
\end{tabular}

Difference between the two production systems for egg is significant $\left(\chi^{2}=92.32, \mathrm{P}<0.0001\right)$

Difference between the two production systems for hen is significant $\left(\chi^{2}=10.28, \mathrm{P}=0.0013\right)$ 


\section{توصيف نظام إنتاج الدواجن العائلي في القطاع الريفي بمحافظة الثرقيةـ مصر}

حسن بيومي غريب | ، ياسر أحمد عبدالعزيز ץ ، محمد عبد الرحمن المناوي ل، رضا السيد حموده r

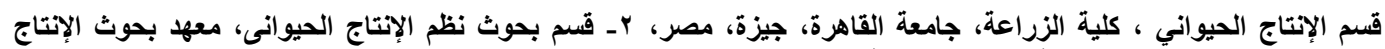

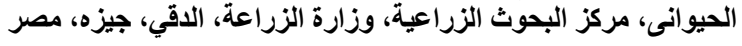

تم جمع مجموعة بيانات طولية (المسح المتكرر) ودراسة استقصائية عبر القطاعات في 24 قرية تابعه لعدد 3 مر اكز في محافظة

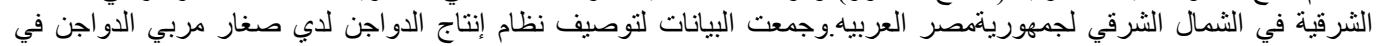

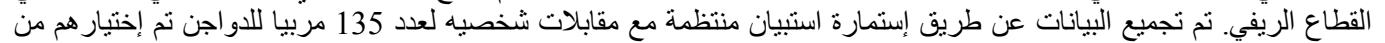

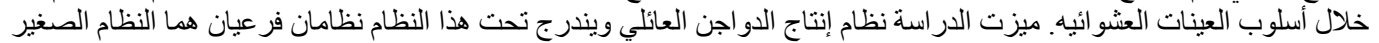

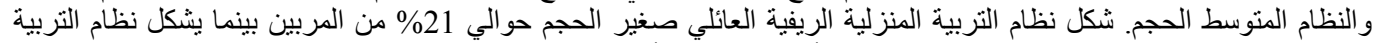

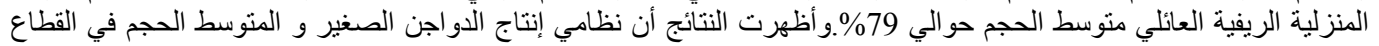

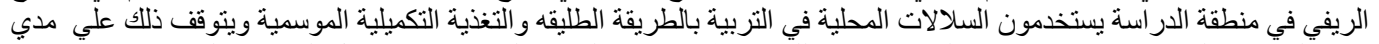

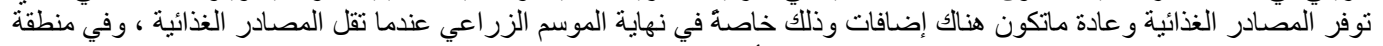

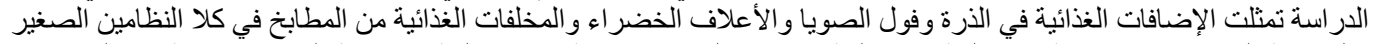

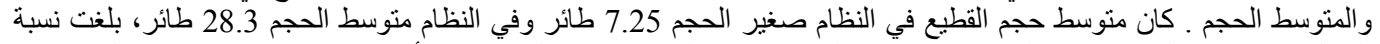

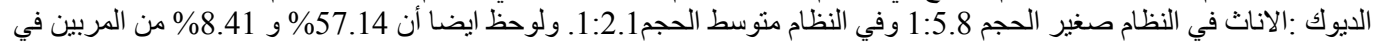

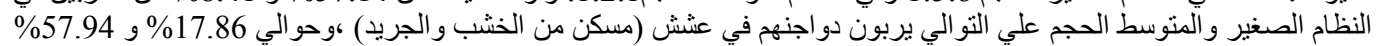

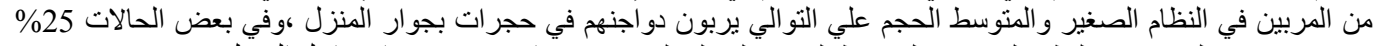
و33.64\% من المربين في النظام الصغير و المتوسط الحجم علي التو الي يربون دو اجنهم في حجرات داخل المن المنزل . 